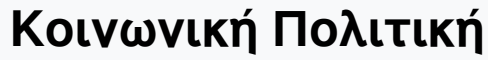

Tóp. 2 (2014)

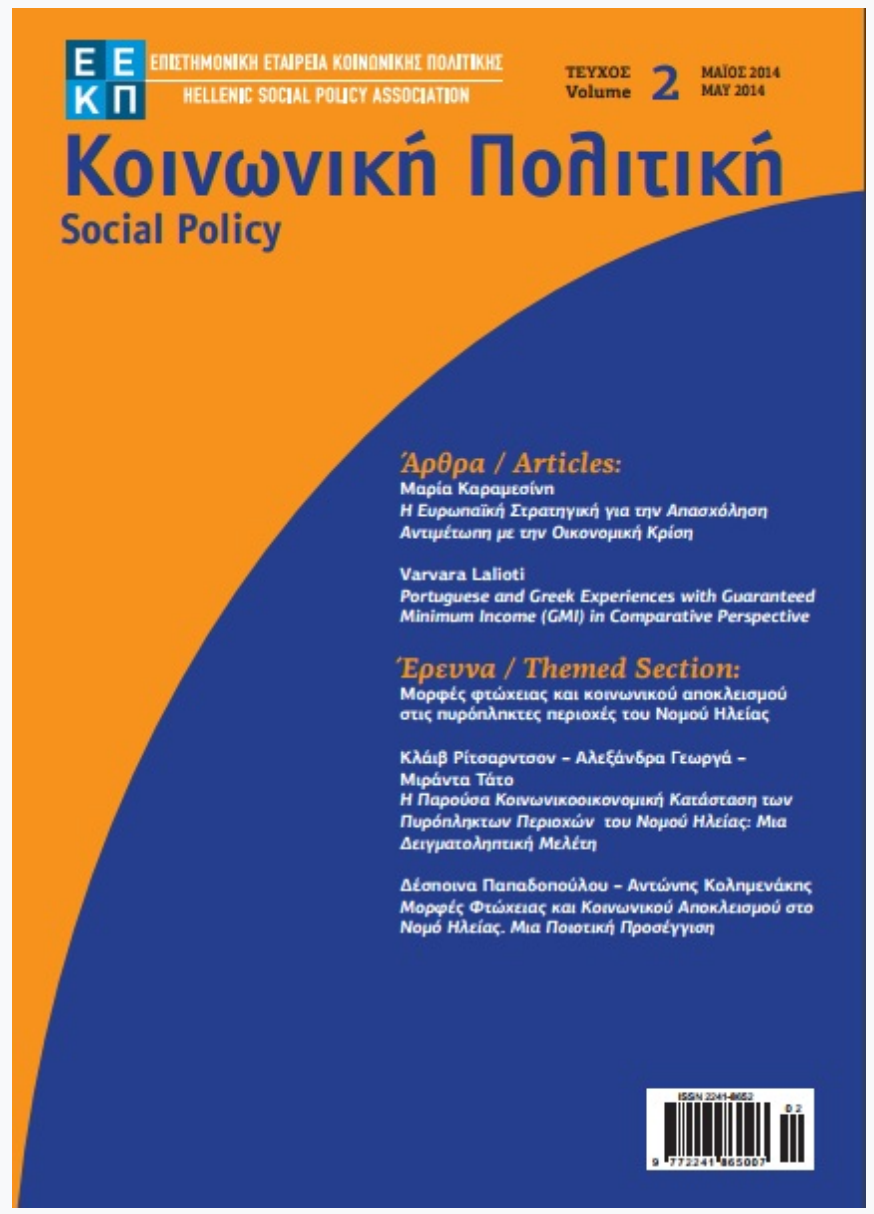

\section{Portuguese and Greek Experiences with Guaranteed Minimum Income (GMI) in Comparative Perspective}

\section{Varvara Lalioti}

doi: $\underline{10.12681 / \mathrm{sp} .10553}$

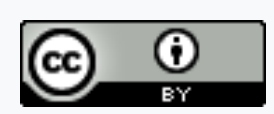

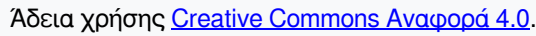

\section{Copyright $\odot$ 2016, Varvara Lalioti}

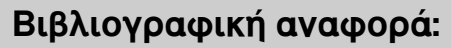

Lalioti, V. (2017). Portuguese and Greek Experiences with Guaranteed Minimum Income (GMI) in Comparative

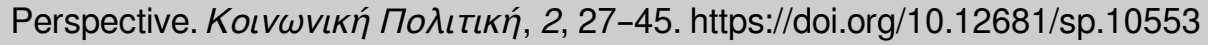




\title{
Portuguese and Greek Experiences with Guaranteed Minimum Income (GMI) in Comparative Perspective
}

\author{
DR VARVARA LALIOTI [DPHIL (OXON)]
}

Freelance Researcher

email: blalioti@gmail.com

\begin{abstract}
Portugal and Greece have divergent histories with regard to Guaranteed Minimum Income (GMI), arguably the principal difference in the two countries' evolutions of social assistance in recent decades. Neither had a GMI when EEC common criteria on sufficient resources and social assistance were issued in 1992. Portugal introduced a pilot programme in 1996 that went operational in 1997. Greece is among only a few European countries never to experiment with GMI. Only recently (in 2012) was a decision reached to launch a pilot GMI scheme, with implementation still forthcoming.

An account for the different Portuguese and Greek GMI experiences emphasizes the importance of actors such as political parties and trade unions. This actor-centred approach argues that the Portuguese GMI success is attributable to a coalition among key domestic policy actors, while ambivalent and fragmented attitudes among Greek policy actors hindered institution. The recent decision for a GMI pilot in Greece should be viewed as a product of the severe economic crisis and state debt obligations that leave little space for ambivalence.
\end{abstract}

\section{Introduction}

Guaranteed Minimum Income (GMI) belongs to the third generation of social assistance schemes, distinguished by the combination of monetary with social insertion measures. As a safety net, GMI aims to ensure individuals' survival despite economic or social breakdown (Alcock, Erskine and May, 2002: 15 and 220), and serves as a measure of a society's progress towards social citizenship (Benassi, 2002). 
Up to the mid-1990s Portugal and Greece, representative cases of a 'southern European' welfare state or regime ${ }^{1}$, both lacked a GMI. This soon changed: Portugal introduced a pilot GMI programme in 1996 that became fully operational in 1997, whilst until 2012 Greece was one of a very few European countries never to have legislated such a scheme. The following explores possible reasons behind the comparatively early and long-lived Portuguese GMI, as against the long-standing 'failure' of the Greek state to establish one.

Notable studies on GMI for the two countries often underscore the salience and particularities of national political agendas and discourses. They include, for Portugal, contributions by Branco (2001), Carlos Rodrigues (2004 and 2011), Eduardo Rodrigues (2006), and Adão (2009); and, for Greece, Matsaganis (2004 and 2013), Matsaganis and Levendi (2012), and the collective 2013 study of the Greek National Institute of Labour and Human Resources.

Comparative approaches are more rare. Among them are a joint article on antipoverty policies in southern Europe by Matsaganis et al. (2003), a volume on welfare state reform in southern Europe edited by Ferrera (2005), and, more recently, Adão (2009: 196-206), who points to the convergence of Portugal's reform agenda with the EEC policy strategy on social assistance, and to the absence of such a convergence in Greece as the key factors behind the 'success' of the Portuguese as against the Greek GMI experiences.

Here we focus most on how governmental actors stand on GMI, while also acknowledging that the action of other key policy actors, such as trade union confederations, can affect relevant policy outcomes. GMI beneficiaries, often extreme outsiders with limited political representation, are forced to rely on such actors to promote their interests (Huber and Stephens, 2001: 18).

In Portugal, the relatively stable party system that emerged in the postRevolution years includes the Social Democratic Party (Partido Social Demócrata, PSD), the Socialist Party (Partido Socialista, PS) and the Portuguese Communist Party (Partido Comunista Português, PCP) as major policy actors in the country's political scene (Freire, 2005: 21-22). The main trade union confederations are the General Confederation of the Portuguese Workers (Confederação Geral dos

\footnotetext{
${ }^{1}$ See e.g. Leibfried (1992), Ferrera (1996), Katrougalos (1996), Andreotti et al.(2001), Amable (2003), Hall and Gingerich (2004).
} 
Trabalhadores Portugueses, CGTP) and the General Union of Workers (União Geral de Trabalhadores, UGT) ${ }^{2}$.

In Greece, a party system of polarized pluralism gave way after 1981 to a predominantly two-party system. The pivotal domestic actors have included the

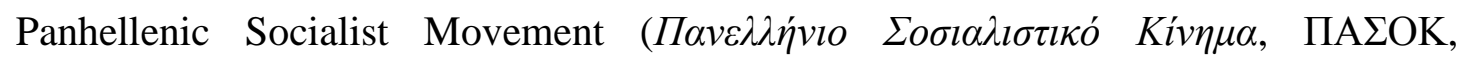
PASOK), New Democracy (NÉ $\alpha \Delta \eta \mu о \kappa \alpha \tau i \alpha, \mathrm{N} \Delta, \mathrm{ND}$ ), and the Greek Communist

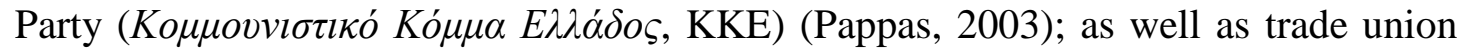

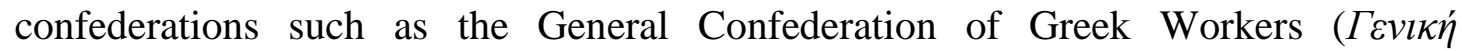

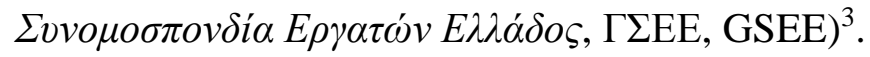

We assume the attitudes of policy actors towards GMI reflect the internal dynamics of given time periods in specific national context (Sotiropoulos, 2005: 288). Exogenous influences on domestic political agendas, such as those exemplified by 'soft-law' instruments like the 1992 EEC Recommendation on common criteria concerning sufficient resources and social assistance, are mild; these depend for implementation on the discretion and thus the interests and ideological preferences of domestic policy actors.

The following draws on interviews ${ }^{4}$, parliamentary archives and secondary sources. It is argued that the existence and persistence of a pro-GMI coalition among domestic policy actors made the Portuguese GMI a relatively timely and durable policy innovation. By contrast, the inconsistent and segmented attitudes of policy actors in Greece set up obstacles to the scheme's institution.

The next two sections discuss the Portuguese and then the Greek GMI experiences. The concluding section synthesizes the main lessons to be learned from this analysis.

\section{A Portuguese Success Story ${ }^{5}$}

\section{A New Game in Town}

The 1990s opened for Portugal with the PSD's electoral triumph in the October 1991 elections with 50.6 percent of the vote nationwide (135 seats),

\footnotetext{
${ }^{2}$ This information draws on data from the European Trade Union Institute.

${ }^{3}$ See note 2 .

${ }^{4}$ Between 2010 and 2012, 22 interviews were conducted in person (in Lisbon and Athens), via Skype or by e-mail, at the discretion of the interviewees and in accordance with their preferences.

${ }^{5}$ Writing on the Portuguese GMI story owes a lot to the invaluable help and generosity of Pedro Adão and Francisco Branco, who offered me inestimable advice and material on the research topic. My work builds on their work, to which I hope to have made a useful addition.
} 
compared to the second-place PS, which received only 29.14 percent of the vote (72 seats $)^{6}$. The centre-right's victory came in a period marked by the increased salience of Europeanization processes, and these were inter alia expressed in the 92/441/EEC Recommendation that urged EEC member-states to establish a GMI.

In the Portuguese case the EEC Recommendation was of special importance, at least symbolically: it was shaped by principles agreed in June 1992, when Portugal held the EEC Presidency. The same PSD government that presided over the Council of Ministers who approved the Recommendation, however, had no intention of establishing such a scheme in Portugal.

Among the explanations advanced for this inconsistency are that the scheme's dossier was inherited from earlier EEC presidencies (Adão, 2009: 74). Among the reasons for the PSD's decision not to establish a national GMI as given by José Albino Silva Peneda, Minister of Employment and Social Security at the time of Portugal's EEC presidency (interview with author), he pointed to EEC Recommendations not being enforceable by law, and to severe budgetary constraints. The first of these claims was falsified a few years later, however, when the Socialists institutionalized a GMI. Likewise, as of 1992 no study had evaluated the potential costs of GMI, leaving the second claim unfounded (Luísa Guimarães, former VicePresident of the Board's Institute for Social Security, interview).

The PSD's decision not to make GMI an issue of the domestic political agenda conforms with the party's profile: increasingly distant from the social democratic identity its name implies (Freire, 2005 and 2010), the PSD's 1992 electoral programme made it clear that the state should avoid the temptation to provide too much to citizens, and instead prioritize initiatives by private entities (PSD, 1992: 1618 and $30-31)$.

By not activating the process that would lead to the establishment of a GMI, nonetheless, the centre-right gave the opposition political capital that it might otherwise not have enjoyed (Branco, 2001: 129-130; Adão, 2009: 82). Now the PCP and especially the PS had the ball, and they would take the best possible position for playing the game. Trade union confederations, along with religious organizations, were also willing to offer support.

\footnotetext{
${ }^{6}$ The data is from the Historical Archive of Parliamentary Election Results (Assembly of the Republic).
} 


\section{Counting Friends and Enemies}

Between 1993 and 1995 the Socialists and the Communists secured for themselves a central role in the GMI debate. Milestones included the parliamentary discussion of the bills 309/VI (March 1994) and 385/VI (May 1994), prepared by the PCP and the PS respectively (Journal of the Assembly of the Republic, 1994a and b). Both invoked the need to conform to the 1992 EEC Recommendation, and still more to compensate for weakening family structures and growing poverty ${ }^{7}$. The timing of these debates, however, in the year before the 1995 general elections, suggests that Europeanization processes and poverty may not have been the only factors that shaped PCP and PS attitudes.

The proposal to establish a GMI was compatible with the ideological profiles of both parties. The PCP's Constitution described the Communists as following the ideas, gains, and historic achievements of the 'April Revolution' (PCP, 2010). Against this ideological background, GMI was considered a tool to help secure better living conditions for all Portuguese citizens, and the scheme proposed was more 'universalist' than that proposed by the PS shortly afterwards ${ }^{8}$. Furthermore, for the traditionally anti-European PCP, with its electoral results declining, this period coincided with attempts to gain greater legitimacy by building bridges with the PS and abandoning Marxist orthodoxy (Bosco, 2001: 351; Costa Lobo, 2006: 9) and the principle that social assistance policies 'destroy the class conscience of the proletariat in an incurable way' (Rühle, 1939).

After years of exclusion from power, on the other hand, the PS saw the GMI as an opportunity to affirm its commitment to protecting low-income groups and to catch up with the European social model (Adão, 2009: 75 and 82). For the Portuguese party most strongly linked with European institutions (Guimarães, interview; also Costa Lobo and Magalhães, 2001: 26), the GMI proposal also conformed to the party's increasing ideological de-Marxification since 1986 (Magone, 2005: 506).

These two parties knew they could count on the mobilization capacity and support of allies, both traditional and more recent. Among their traditional allies were the two major union confederations, which enjoyed strong links with both parties. The

\footnotetext{
${ }^{7}$ Journal of the Assembly of the Republic, 1994a: 1747, 1749 and 1751; Journal of the Assembly of the Republic, 1994b: 2474-2489; Branco, 2001: 129-130.

${ }^{8}$ Journal of the Assembly of the Republic, 1994a: 1746-1768 (on the PCP proposal); Journal of the Assembly of the Republic, 1994b: 2474-2489 (on the PS proposal).
} 
UGT and the CGTP had already adopted a pro-GMI position (USS/CGTP-In, 1994; also Branco, 2001: 124).

The unions pursued this course in the expectation that GMI would be less a neo-charity social assistance scheme and more of a programme stressing social inclusion, in harmony with the labour movement's permanent demand for protection of the right to employment (Paulo Pedroso, former President of the National GMI Commission, and former Secretary of State of Employment and Professional Training, interview). If the unions, moreover, always strived for a society that does not need schemes of this kind, they were nonetheless fully aware of the Portuguese socioeconomic reality and acknowledged that a GMI was vital for mitigating conditions of extreme poverty in the short-term (João Proença, General Secretary of the UGT, interview; also CGTP-In, 1996 and 1998; UGT, 1998: 9-10).

Especially for the PS, which was less opposed to privatization, more recent allies were found in religious organizations such as Cáritas Portuguesa and the Misericórdias. Their commitment to solidarity accounts for their pro-GMI attitudes (Eugénio Fonseca, President of Cáritas Portuguesa and representative of the Private Institutions of Solidarity [Instituições Particulares de Solidariedade, IPSS] in the National Commission for Minimum Income, interview).

Against this backdrop, the Socialists' GMI proposal in particular stressed the need to involve a broad range of policy actors long active in the fight against poverty in the scheme's design and implementation. It was anticipated that they would contribute to the scheme's efficiency (Journal of the Assembly of the Republic, 1994a: 1759 and 1994b: 2477). Due to the salience of the principle of subsidiarity in the Portuguese welfare state, moreover, the support and involvement of such actors would increase the legitimacy of the scheme and associated government actions, facilitating the GMI's entrenchment in Portuguese society and culture (Adão, 2009: 66).

The Socialists' decision to mobilize policy actors influential in the field of social assistance for the sake of GMI contrasted with the PSD's 'autistic' style, particularly of its leader Cavaco Silva (Lisi, 2006: 61-62). Between 1992 and 1994, the PS leader, António Guterres, had already asked for the support of civil society actors to bring about what he called a 'legislative contract', i.e. an election programme that emphasized genuine partnerships between state and civil society (Stock and Magone, 1996; Magone, 2005: 509). 
Negative experiences of coalitions with the centre-right and a lack of partners on the left forced the PS to stand alone in the forthcoming elections (Lisi, 2006: 6162). In these circumstances, like Britain's New Labour, whose 'Third Way' pragmatism he largely emulated, Guterres was building a new majority to put an end to the centre-right's long reign (Magone, 2005: 508-509). The GMI proposal might thus also be viewed as an attempt to broaden the party's support base.

Although the PCP and PS proposals failed to obtain a majority vote in the legislature, the two parliamentary debates put GMI squarely on the political agenda. GMI became a central part of the electoral campaign and a top issue in the media. Members of union confederations, especially the UGT, and representatives of religious organizations expressed their support for a GMI on television. In the press and in all his debates with Cavaco Silva, Guterres underlined the need for a GMI (Pedroso, interview).

He would soon keep his promise.

A Promise Kept: The Establishment of a GMI and the Strengthening of a ProGMI Coalition

The Socialists won the October 1995 elections with 43.93 percent of the national vote and 112 seats against the PSD's 34.02 percent and 88 seats ${ }^{9}$. A few months later, the PS started the process of institutionalizing a national GMI. In the relevant parliamentary debate (May 1996), Ferro Rodrigues, the new Minister of Employment and Solidarity, referred to the Socialists' aim to reinforce the support base of the scheme and secure its entrenchment within Portuguese society (Journal of the Assembly of the Republic, 1996a: 2214). Representatives of key policy actors, such as the trade unions and the religious organizations, participated in drafting the 1996 GMI bill advanced by the PS (25/VII), which effected the scheme's institutionalization (Fonseca, interview; also Journal of the Assembly of the Republic, 1996a: 2214; Branco, 2001: 139 and 142-143).

The monetary component of the Rendimento Minimo Garantido (RMG) (Law 19A/1996) bridged the difference between a family's income and the social pension ${ }^{10}$, and was combined with a social integration programme (Rodrigues, 2004: 5 and Rodrigues, 2006: 179). RMG was introduced on a one-year experimental basis at the

\footnotetext{
${ }^{9}$ See note 6 .

${ }^{10}$ At that point 22,900 escudos, whereas the minimum salary was 58,900 escudos.
} 
insistence of Paulo Pedroso, then Secretary of State for Employment and Training (Pedroso, interview). This decision partly reveals, once again, the priority the Socialists gave to enforcing and consolidating partnerships with other actors. The PS government reckoned that time was needed to get them more involved in building a national network of support for the scheme's social inclusion component (Pedroso, interview; also Melícias and Pedroso, 1997: 101; Rodrigues, 2006: 184).

It was not long before the Socialists further demonstrated their commitment to partnerships with influential policy actors in the cause of advancing the newly established scheme.

\section{United We Stand, Divided We Fall}

The experimentation period was shorter than expected, an outcome which Pedroso (interview) attributes to the existence of a very broad consensus behind the scheme in Portuguese society. In less than a year, more than 3,500 territorial actors (local governments), along with non-governmental organizations and local charities, submitted applications expressing their interest in participating in the RMG programme. Social solidarity proved to be particularly strong: in 146 local RMG projects, the actors/organizations involved totalled 475 municipalities, 119 IPSS, 74 Misericórdias, two Mutual Aid Societies, seven business associations, two union confederations, and 107 other entities aimed at the promotion of social purposes (Melícias and Pedroso, 1997: 13, cited in Rodrigues, 2006: 184).

To enforce linkages between these actors, the government proceeded to create a National GMI Commission and local monitoring commissions (Pedroso, 1998: 8). Although the financing of the RMG that came into force in July 1997 (Decree-Law 196/1997) was a governmental responsibility, organizations such as Cáritas Portuguesa, CGTP, and UGT were asked to collaborate in these commissions together with entities representing the government and territorial actors. In this context, trade unions, for instance, provided the National GMI Commission with information about the working poor (Proença, interview).

In addition to the government's effort to consolidate and expand the pro-GMI coalition via formal state structures such as the aforementioned Commission, increasingly decentralized entities emerged that played a pivotal role in the RMG accompanying services. Examples were, at the parish level, the Social Commissions (Comissões Sociais de Freguesia), and Local Councils of Social Action (Conselhos 
Locais de Acção Social). Municipalities and religious organizations were, once again, represented in these commissions and councils (Guimarães, interview).

Just a few months later, a poll conducted by a team evaluating the RMG's experimental phase corroborated its wide acceptance within Portuguese society: 92.8 percent of respondents ${ }^{11}$ considered the RMG a scheme that was needed in Portugal (Capucha et al., 1998: 201-202; Adão, 2009: 91). Another indicator of the scheme's popularity was that by assuming the scheme's paternity, Ferro Rodrigues became one of the most popular ministers (Inácio, 2004). Against this backdrop, the PSD softened its attitude towards the scheme and publicly admitted its utility (Público, 1999: 7).

The following years signalled, nevertheless, the beginning of a new period for the GMI in Portugal, one that continues today (Guimarães and Pedroso, interviews).

\section{The Post-2000 GMI Experience: Change, Change Again, but Also Survival}

In early 2000 the Court of Auditors conducted a review that confirmed the existence of irregularities in the scheme's implementation, and the weakness of its social integration component (Court of Auditors, 2000). The latter was supposed to facilitate beneficiaries' access to the labour market via participation in vocational training and community work programmes (Rodrigues, 2004: 4). After the broadening and consolidation of the pro-GMI consensus among a series of key policy actors/organizations, the years after the 2000 audit would be marked by a debate on the need to redesign the scheme.

Criticisms were expressed not only by those who had opposed GMI in the first place, but also by actors favourable to the scheme, who asked for changes to increase its efficiency. The unions' criticisms focused mainly on the RMG's role in reinforcing privatization through the instrumentality of the IPSS, and on the RMG's social integration component. The former reflected the CGTP's firm anti-capitalist ideology, contrasting with the UGT, which had been more receptive to the notion of a socialist 'third way' (Estanque, 2009).

Both the CGTP and the UGT unsurprisingly agreed on the need to reinforce the scheme's social integration component. Labour market integration is a traditional labour movement concern (Cristovam, 1999: 5-6). Religious organizations such as Cáritas Portuguesa, on the other hand, indicated that the RMG had to be provided in

\footnotetext{
${ }^{11}$ Slightly more than 1,000 people.
} 
accordance with looser residence criteria to cover immigrants (Público, 2002); and stressed the need for the RMG monitoring mechanisms to become more efficient (Fonseca, interview).

In a context marked by the scheme's broad acceptance by Portuguese society and acknowledgments from RMG beneficiaries themselves of the crucial role a proGMI coalition played in their experience (Rodrigues, 2006: 495), reform was the only alternative. The centre-right coalition government of PSD and CDS-PP (Democratic and Social Centre-People's Party, Centro Democrático e Social-Partido Popular) that emerged under Durão Barroso after the March 2002 elections, in which the two parties combined for 49.84 percent of the national vote (119 seats) as against 38.6 percent (96 seats) for the PS ${ }^{12}$, advocated a change in the scheme's philosophy that would strengthen the RMG's social integration component (Peneda, interview; also Journal of the Assembly of the Republic, 2002: 16). To stress activation measures, the government furthermore altered the programme's name to 'Social Integration Income' (Rendimento Social de Inserção, RSI) (Law 13/2003).

The RSI introduced inter alia stricter eligibility rules, a lower ceiling for complementary benefits, and regulations to control fraud. Whilst the scheme's monetary component topped up household income so it would reach the noncontributory pension level (Rodrigues, 2011: 3), the RSI also included support programmes for beneficiaries in policy areas such as housing, health and education.

Further modifications have since been made. In the shadow of the public debt crisis, the PS government of José Socrates and the succeeding PSD and CDS-PP coalition government of Pedro Coelho implemented a series of changes that included the abolition of some supplementary benefits connected with the scheme and the decrease of its monetary component ${ }^{13}$ (Decree-Law 70/2010; Administrative Act 257/2012; Decree-Law 133/2012; Decree-Law 221/2012; Decree-Law 13/2013; also Institute of Social Security, 2013).

The fundamental point, nonetheless, is that the scheme survived all criticism and changes. The RMG/RSI has resulted, moreover, in substantial improvements in measures of poverty intensity and severity (Rodrigues, 2004), as well as in the

\footnotetext{
${ }^{12}$ See note 6.

${ }^{13}$ The amount varies depending on the composition of the family and the household income.
} 
housing, health and education of beneficiaries (Rodrigues, 2006: 191), who in November 2013 equalled to approximately $235,000^{14}$.

Overall, the story of the RMG/RSI in Portugal is one of success, and largely explainable by the existence and further enforcement of a pro-GMI coalition of domestic policy actors within the context of a broad consensus on the scheme.

\section{The Curious Case of the Greek GMI}

The Road to Stalemate No.1

In stark contrast to the Portuguese GMI experience, the relevant debate in Greece was marked among the key policy actors by a more rhetorical or at best fragmented interest, resulting in a long-lived inertia. In 1998, Georgios Sourlas, a deputy from the centre-right party of ND became the first to submit a parliamentary motion for a guaranteed minimum income mechanism. The motion was presented as a necessity of conforming with the 1992 EEC Recommendation and of reducing the high poverty rate (Sourlas, interview; also Parliamentary Proceedings, 1998b).

In order to move the social conservatives within Sourlas' own party, the motion's introductory report described poverty as disastrous for the central cell of the Greek nation, defined as the family. For the sake of the family, the proposed scheme combined a monetary allowance with in-kind benefits, and not with the social insertion measures of a 'traditional' GMI programme.

Sourlas (interview) represented ND's social/populist right wing. He considers Panayotis Kanellopoulos, a prominent centre-right politician who believed in combining a liberal model of development with social-democratic principles, as his mentor. The timing of the Sourlas bill, exactly one day after the Standing Parliamentary Committee on Social Affairs had approved a draft law for a national system of social care (Parliamentary Proceedings, 1998a), is also remarkable. Regardless, however, of whether the initiative can be explained by Sourlas' ideological preferences or other interests, the motion forced political parties to take a stance on a guaranteed minimum income mechanism. The 1998 parliamentary debate on the latter occurred among ND, PASOK, Synaspismos and KKE, which at that point commanded 108, 162, 10 and 11 parliamentary seats, respectively ${ }^{15}$.

\footnotetext{
${ }^{14}$ Data from the Ministry of Solidarity, Employment and Social Security.

15 The data is from the Greek Ministry of Interior.
} 
The main argument used by the overwhelming majority of ND deputies to avoid supporting Sourlas' motion was that the proposed mechanism would benefit an increasing number of immigrants at the expense of the Greeks in real need (Sourlas, interview). In an effort to convince ND deputies to support it, the motion's final version actually favoured an 'ethnicity-based selectivity'16, stipulating that beneficiaries would only be Greek citizens.

The ensuing parliamentary discussion (July 1999) is indicative of the minimal interest among the Greek political parties toward establishing a guaranteed minimum income mechanism (Parliamentary Proceedings, 1999: 489-510). The representative of PASOK, MP Evangelos Vlassopoulos, argued inter alia that the motion exaggerated the extent of poverty in Greek society (Parliamentary Proceedings, 1999:

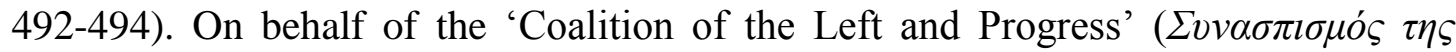

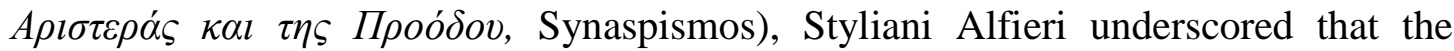
proposal wrongly discriminated between the middle class and the neo-poor, and that it contributed to the one-dimensional development of 'allowance policies' (Parliamentary Proceedings, 1999: 496-497).

The KKE, at that point the strongest party of the traditional left in Greece, likewise opposed the motion, on the ground that the solution to poverty lay in securing the right to employment, not in policies distracting the poor from the class struggle necessary to combat marginalization (Parliamentary Proceedings, 1999: 495). KKE's position was thus strikingly different from that of the PCP in Portugal; a differentiation reflecting how the traditionally anti-European KKE has remained an orthodox Communist party, closely bound to Marxism, unlike other southern European Communist parties, which have become more ideologically flexible (Bosco, 2001: 330 and 341).

Unsurprisingly, Sourlas' motion was voted down without need of a roll call. The speaker of the Parliament asked those in favour to stand, then announced that there were too few to pass the proposal (Parliamentary Proceedings, 1999: 509). Thus, the parliamentary proceedings do not tell us even how many ND deputies eventually supported the proposal.

This was the situation on the eve of the April 2000 elections, when PASOK put GMI back on the political agenda despite the fact that intra-party workshops

\footnotetext{
${ }^{16}$ See Matsaganis, 2011: 210-211 and 223 on the constraints posed by migration and racist views to social protection.
} 
revealed no clear tendency for or against the scheme's introduction ${ }^{17}$. This effort would ultimately result in a second stalemate.

\section{The Road to Stalemate No.2}

After the Socialists' election victory with 43.79 percent of the national vote, just ahead of the second-place ND with 42.74 percent $^{18}$, the Minister of Employment and Social Insurance, Tasos Giannitsis (interview) formed a group of experts to discuss anti-poverty measures, GMI included. The scheme's establishment conformed with the new prime minister's profile as a modernizer of the state apparatus and as a statesman capable of resolving social antagonisms in accordance with European principles (Simitis, 1989 and 1990). Nevertheless, the group abandoned the idea of a GMI. A central argument was that the causes of poverty differed for different population groups, so that the scheme would be inadequate to combat them (Ministry of Labour and Social Security, 2001: 7-19). They instead proposed an increase in interventions focused on selected groups, a strategy the government adopted.

To Matsaganis' claim (2004: 20) that the abandonment of the GMI proposal was due to fears of the scheme's financial repercussions at a time when the country's integration into the European Monetary Union (EMU) was the main policy objective, Giannitsis (Interview) adds three more reasons: first, that the government had opted for measures, such as an increase in the pension provided by the Agricultural

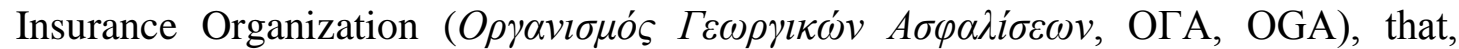
along with the minimum pension, could be regarded as functional equivalents to a GMI. Second, the Ministry of Economy and Finance and its Minister, Nikos Christodoulakis, opposed a GMI. The Ministry, specifically its tax agency, would have to perform many of the procedures connected with its introduction, while receiving little credit for a scheme that another Ministry would design and announce. The economy and finance ministry instead favoured a "Milton Friedman" type of GMI, i.e. a negative income tax system, in which individuals earning a certain income level would pay no taxes. Third, Giannitsis (interview) underscores the existence of an environment hostile to the scheme, because of the unions' fierce reaction to the government's stated intent to reform the social insurance system.

\footnotetext{
${ }^{17}$ Information based on the interview with Christos Polyzogopoulos, former president of the General

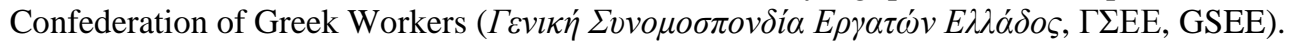

${ }^{18}$ See note 15.
} 
Is Giannitsis right about the latter? The official journal of the union

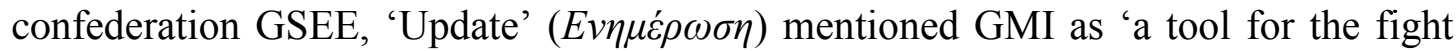
against poverty' (Update, 2003: 12). If not openly hostile, however, the trade union leadership was hesitant about the prospect of establishing the scheme: even prominent labour movement cadres who did not oppose GMI feared that it would lead to the open contestation and subsequent abolition of the national minimum wage, and a decrease of the minimum pension (Polyzogopoulos, interview; Savvas Rombolis, the research director of the GSEE Institute of Labour, interview).

A set of complementary reasons arguably explain this attitude. An institutionalized GMI might shrink the slice of the pie going to 'insiders', thus reducing their incentive to welcome the scheme. In contrast, very strong forces were ready to defend accumulated privileges and existing inequalities. As a high-profile Greek economist, who prefers to remain anonymous, argues (Anonymous, interview), trade union confederations in Greece are particularly reluctant about policy initiatives that will secure the rights of the lowest socioeconomic strata. As he explains, the confederations largely represent the interests of the most privileged employees, i.e. the staff of the public sector and public utility organizations. Therefore, they are not particularly solidaristic (also Matsaganis, 2011: 41-42 and 80-81).

The GMI debate reinforced cleavages in the ruling party. In December 2000, Theodoros Tsoukatos, an associate of Prime Minister Kostas Simitis whose relationship with the latter had been deteriorating (To Vima, 2008), advanced a bill signed by 52 of PASOK's 158 deputies favouring introduction of a GMI. At a time when the government had opted for alternative policies, Simitis saw the proposal as a vengeful act of internal opposition (Ethnos on Sunday, 2000). Tsoukatos' proposal was never discussed.

After a one-month break the discussion within PASOK on the possibility of establishing a GMI began again, and continued for a few more months (Polyzogopoulos, interview). The governing party's intentions were still unclear, however (also Matsaganis, 2004: 22). Indicative of the Socialists' inconsistency on the issue was that among those who supported Tsoukatos' proposal was Vlassopoulos, the same MP who presented PASOK's objections to Sourlas' 1998 motion ${ }^{19}$.

\footnotetext{
${ }^{19}$ This information draws on a media report issued by Sourlas' political office (29 July 1999).
} 
In July 2003, the authors of the 'National Action Plan for Social Inclusion, 2003-05' once again rejected the GMI option (Ministry of Labour and Social Security, 2003: 30-32). Similarly, rumours of a governmental intention to establish a GMI on the eve of the 2004 elections were soon falsified in practice (Matsaganis, 2004: 23).

PASOK was not the only political party with an ambivalent attitude towards the issue, however. In an effort to build a 'social-friendly' profile, as opposed to the neo-liberal profile of the earlier ND government under Konstantinos Mitsotakis (Papadokostopoulos, 2007), ND's leader Kostas Karamanlis flirted for several years with the GMI prospect, both while in opposition and in government (Matsaganis, 2004: 22-25; Tsouparopoulos and Triantafyllou, 2006). Partly because of internal opposition to the scheme within ND, and partly because of the political cost linked to the possibility of abolishing a large number of welfare benefits for the sake of a GMI, ND abandoned the idea (Sourlas, interview).

In fact, Synaspismos, at that point the weaker leftist parliamentary party, was the only party to submit bills for a $\mathrm{GMI}^{20}$. The first (in 2002) was never discussed; it had been advanced after the statutory deadline for parliamentary debate. The second (in 2005) was blocked from a vote on grounds that the Constitution (Article 73, Paragraph 3) permits no legislation to be passed that would cause a significant budget increase (Parliamentary Proceedings, 2005a and 2005b).

As Dragasakis argues (interview), Synaspismos opted for a more 'conservative' GMI, having in mind the examples of Portugal and Italy rather than the Scandinavian experience. He asserts this choice was largely due to the ambivalent (or even hostile) views within PASOK and ND, and the lack of a social movement to support Synaspismos' proposal, again in contrast to the Portuguese GMI experience.

Dragasakis (interview) admits that there was confusion over the GMI concept even within Synaspismos, largely attributable to the fact that the neo-liberal Milton Friedman was among the very first to have spoken in the scheme's favour, albeit in the form of a 'negative income tax'. Furthermore, Dragasakis underscores that whenever Synaspismos' GMI proposals were presented to broader audiences, participants always ended up asking questions concerning their own financial and social problems rather than about the proposed scheme.

\footnotetext{
${ }^{20}$ This paragraph draws on the interview with Giannis Dragasakis, MP of Synaspismos.
} 
Although no vote followed the discussion of the 2005 motion, the relevant debate is telling. ND's 'official' position was against establishing a GMI, with only a few ND deputies expressing views in favour (Parliamentary Proceedings, 2005b: 2152, 2155, 2162 and 2164). PASOK's stance was also far from unanimous. Tonia Antoniou, in her presentation of PASOK's 'official' position, accepted the need for a GMI (Parliamentary Proceedings, 2005b: 2171). High-profile party members such as Nikos Christodoulakis, however, claimed that the Simitis governments' social assistance policy initiatives already corresponded, in practice, to an institutionalization of GMI, and that the proposal might lead to the retrenchment of purchasing power among the financially weak (Parliamentary Proceedings, 2005b: 2167-2168).

Finally, KKE remained loyal to its stand against GMI as a manifestation of the political system's inability to secure citizens' rights to employment, arguing that GMI beneficiaries would end up used as cheap labour by capitalists (Parliamentary Proceedings, 2005b: 2155-2158; also Rizospastis, 2004). Viewed in conjunction with the Synaspismos proposals, KKE's position reflects the high ideological fragmentation of the Greek left, as compared to the Portuguese (Kouvelakis, 2011: 29-31).

The GMI card was played for the last time on the eve of the 2007 elections, this time by ND (Tsouparopoulos and Triantafyllou, 2006). Karamanlis won the elections with 41.84 percent of the vote nationwide against PASOK's 38.1 percent $^{21}$, but once again ND did not move to establish a scheme.

A new period followed both for the Greek state and the GMI, however.

\section{The Final Act}

The years since 2008 have seen the combined impact of a severe economic crisis and of the austerity measures adopted first by George Papandreou's socialist government (in 2010 and 2011) and then by a coalition government under ND's new leader, Antonis Samaras, in power since June 2012. In exchange for unprecedented rescue packages, both governments committed to meeting the rules of loan agreements and the so-called Memoranda agreements with the European Commission (EC), the European Central Bank (ECB) and the International Monetary Fund (IMF).

\footnotetext{
${ }^{21}$ See note 15.
} 
Ratified by Parliament amid fierce protest, the new policies aimed inter alia at significantly reducing public spending and effecting structural change in the administrative machinery ${ }^{22}$.

Against this backdrop, the Medium-Term Fiscal Strategy for 2013-2016 stipulated the institutionalization of a pilot GMI to be initiated in two regions starting in January 2014 (Law 4093/2012, Subparagraph IA.3). The credit for the pilot is 20 million Euros ${ }^{23}$. A decision for or against a permanent GMI nationwide will be taken after the pilot is evaluated.

This decision may appear paradoxical, given past ambivalence toward GMI among key policy actors. In a time marked by the unprecedented consequences of the crisis and the country's massive obligations to creditors, demands for a GMI such as the one expressed by the IMF (IMF, 2012: 19-20; Matsaganis, 2013: 13) have left little space for ambivalence. The scheme's institutionalization is part of a plan targeting a radical reform of the highly segmented and ineffective social expenditures in Greece, and conforms with the country's obligation to legislate new welfare programmes for vulnerable population groups (Law 3845/2010, Article 2; also Matsaganis, 2013: 14; Amitsis, 2013: 69-70).

Extremely strong pressures on the domestic policy arena, as opposed to the mild ones of the 1992 'soft-law' EEC Recommendation, increase the incentive for policy actors to break through the sclerosis surrounding GMI. The scheme provides the coalition government under Samaras an opportunity to express interest in the needs of the lowest socioeconomic strata at relatively low cost and with possible electoral gains.

Within the government, GMI found a new ally in the Democratic Left

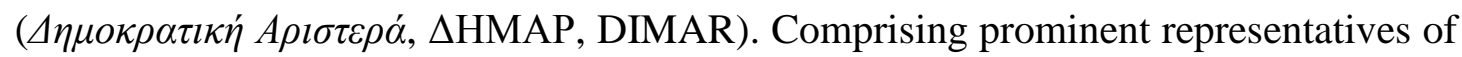
the reformist left, DIMAR received 6.25 percent of the national vote in the May 2012 elections ${ }^{24}$ and participated in the government until June 2013. It was outspoken in its support for GMI (Democratic Left, 2012; Matsaganis, 2013: 14; Kostoulas, 2013).

Meanwhile, the political scenery is undergoing drastic transformations, with a small party previously without hope of building a government, Synapismos (now the 'Coalition of the Radical Left', $\Sigma$ YPIZA, SYRIZA) becoming the strongest contender

\footnotetext{
${ }^{22}$ See e.g. the 'repository' of the Crisis Observatory http://crisisobs.gr/en/repository/.

${ }^{23}$ Journal of the Greek Government, vol. A, no. 229/2012, p. 5697.

${ }^{24}$ See note 15.
} 
for power almost overnight in the 2012 elections. The government's GMI initiative deprives SYRIZA of the opportunity to benefit politically from the GMI's establishment (see SYRIZA's 2012 electoral programme; Matsaganis, 2013: 13-14).

The dire economic context makes the establishment of a guaranteed safety net, as the proposed GMI promises, all the more urgent. Somewhat alarmingly, and as an indication of the improvisational and procrastinating nature of the Greek state machinery, as of March $2014^{25}$ the ministerial decisions relating to the scheme have yet to be issued and, thus, the GMI pilot is far from starting on schedule.

Furthermore, the Ministry of Employment and Social Protection has asked the World Bank for a study on the design and implementation of the proposed GMI. This will arguably further delay and jeopardize the launch of the pilot scheme. In a country where support for the scheme among policy actors remains largely segmented ${ }^{26}$, the danger is that any GMI effort will prove very short-lived, as was the case with the national GMI in neighbouring Italy.

Thus, broadening the support base for the scheme, alongside a well-designed implementation, is a gamble that the government cannot lose.

\section{Conclusions}

The Portuguese experience illustrates the importance of having and reinforcing a pro-GMI domestic coalition among key policy actors for the establishment and maintenance of such a scheme. PSD's refusal to institute GMI left room for PCP and PS to put it on the domestic political agenda. The ideological preferences and interests of these actors explain their stance, just as the ideological preferences and interests of the trade union confederations and religious organizations in Portugal account for their support from the very beginning.

The Socialists attempted to broaden the existing consensus further, first as part of their election strategy, and later to increase the GMI's effectiveness and consolidate its place in the Portuguese welfare state. The scheme's high level of societal acceptance, reflected in the shorter than anticipated experimentation period, also led the centre-right parties to soften their attitude, thus securing the GMI's survival.

\footnotetext{
${ }^{25}$ At the time of this writing.

${ }^{26}$ See e.g. Matsaganis, 2013: 26; National Institute of Labour and Human Resources, 2013: 94-95; Rizospastis, 2013: 5; Poulakidas, 2013.
} 
The Portuguese experience indicates the relatively low degree of polarization between the left and right ideological blocs with respect to social issues (Freire, 2005: 32). In a similar vein, the positive stance of Portuguese unions towards GMI is related to the relatively unfragmented nature of Portugal's labour movement (Ioannou and Kjellberg, 2005: 346 and 354-355). This has contributed to the pursuit of common policies by the different confederations.

Fishman (2010: 288-289) has argued that a broadly shared commitment among all major political actors to address social concerns through state action is one of the legacies of the Carnation Revolution. In an environment already largely favourable to GMI, one factor behind the Socialists' insistence on building consensus and entrenching the coalition in its favour may be that the spirit of the Revolution, a spirit particularly sensitive to collectivity and collective action, is still alive and well in Portugal.

In stark contrast to the Portuguese experience, the rhetorical or at best fragmented interest in GMI among Greek policy actors resulted in the state's longstanding 'failure' to establish a scheme. Although both PASOK and ND flirted with GMI on the eve of general elections, establishment was hindered by the far from unanimous support within each of the two parties. Similarly, the traditionally fragmented left splintered over the scheme, while trade unions distrusted it.

Historical trends have reinforced fragmentation of Greek trade union associations along political lines, contributing to their failure to represent all groups of Greek citizens (Someritis, 1933: 52). Different political factions constitute different organizations within the same confederation, making it harder for the Greek labour movement to adopt a uniform stance even on issues of common sectoral concern. This has arguably hampered the development of a political culture that enables consensual reforms, especially with respect to social issues and the well-being of 'outsiders'.

The recent Greek decision for a pilot GMI should be viewed as a result of the country's severe crisis and massive debt, which have forced introduction of the GMI on the domestic political agenda. The scheme provides the Greek coalition government with a chance to show interest in low-income groups for a limited economic cost and with possible electoral gains; and it prevents the strongest opposition party, SYRIZA, from playing the GMI card in the next elections.

Whilst delays in the launch of the pilot GMI illustrate the deficiencies of the Greek state apparatus, the scheme's viability rests not only on the need for a well- 
designed implementation, but also on the broadening of the support base among policy actors and within society: in other words, on the growth of a political culture that will favour consensual policy reforms for the sake of 'outsiders', which appears to be quite weak in Greece. In that respect, the Portuguese experience is particularly didactic.

\section{References}

Adão, P. (2009), Waving the European Flag in a Southern European Welfare State: Factors Behind Domestic Compliance with European Social Policy in Portugal, Florence: EUI.

Alcock, P., Erskine, An. and May, M. (eds) (2002), The Blackwell Dictionary of Social Policy, Oxford: Blackwell.

Amable, B. (2003), The Diversity of Modern Capitalism, Oxford: Oxford University Press.

Amitsis, G. (2013), 'Principles and Operational Frameworks for a General System of Minimum Income in Greece', in National Institute of Labour and Human Resources (ed.), Guaranteed Minimum Income: Approaches and Proposals in View of the Pilot Implementation of the Scheme, Study no. 8/2013, pp. 57-83 [in Greek].

Andreotti, Al. et al. (2001), 'Does a Southern European Model Exist?', Journal of Contemporary European Studies, vol. 9, no. 1, pp. 43-62.

Benassi, D. (2002), Between Welfare and Poverty, Milan: FrancoAngeli [in Italian].

Bosco, An. (2001), 'Four Actors in Search of a Role: The Southern European Communist Parties', in N. P. Diamandouros and R. Gunther (eds), Parties, Politics and Democracy in the New Southern Democracy, The Social Science Research Council, Baltimore and London: Johns Hopkins University Press, pp. 329-387.

Branco, Fr. (2001), A "Lunar Phase" for Social Rights -Virtues and Limits of the RMG as Citizenship Right in Portugal, Social Work PhD Thesis, Pontifical Catholic University of São Paulo, April [in Portuguese].

Capucha, L. et al. (1998), Guaranteed Minimum Income: Evaluation of the Experimental Phase, Lisbon: MTSS [in Portuguese]. 
CGTP-In (1996), Report of Activities, 8th Congress, May-June, Lisbon [in Portuguese].

CGTP-In (1998), CGTP Conference - For the Defence and Improvement of Social Security, 23 April [in Portuguese].

Costa Lobo, M. (2006), From Democratic Consolidation to Quality of Democracy: The European Union and the Portuguese Political Parties, Working Paper 20, Lisbon: Institute of Social Sciences, University of Lisbon [in Portuguese].

Costa Lobo, M. and Magalhães, P. C. (2001), 'From "Third Wave" to "Third Way": Europe and the Portuguese Socialists (1975-1999)', Journal of Southern Europe and the Balkans, vol. 3, no. 1, pp. 25-35.

Court of Auditors (2000), Audit of the Guaranteed Minimum Income. Allocation and Control Systems, Audit Report no. 2/2000-2. a S [in Portuguese].

Cristovam, M. L. (1999), 'One-Year Experiment with the Guaranteed Minimum Income Examined', European Industrial Relations Observatory (EIRO).

Democratic Left (2012), Programmatic Proposals [in Greek].

Estanque, El. (2009), 'Portuguese Trade Unionism: A "Brief" Balance', in Ideas Behind Great Decisions: OPS-Journal of Socialist Opinion, no. 1/2/3/4, pp. 2328, Lisbon: 'Campo da Comunicação’ Editions [in Portuguese].

Ethnos on Sunday (2000), 'Interview of Tilemahos Hitiris', 10 December [in Greek].

Ferrera, M. (1996), 'The Southern Model of Welfare in Social Europe', Journal of European Social Policy, vol. 6, no. 1, pp. 17-37.

Ferrera, M. (ed.) (2005), Welfare State Reform in Southern Europe. Fighting Poverty and Social Exclusion in Italy, Spain, Portugal and Greece, London: Routledge/EUI Studies in the Political Economy of Welfare.

Fishman, R. (2010), 'Rethinking the Iberian Transformations: How Democratization Scenarios Shaped Labor Market Outcomes', Studies in Comparative International Development, vol. 45, no. 3, pp. 281-310.

Freire, An. (2005), 'Party System Change in Portugal, 1974-2005: The Role of Social, Political and Ideological Factors', Portuguese Journal of Social Science, vol. 4, no. 2 , pp. 21-40.

Freire, An. (2010), 'A New Era in Democratic Portugal? The 2009 European, Legislative and Local Elections', South European Society and Politics, vol. 15, no. 4, pp. 593-613. 
Hall, P. and Gingerich, D. W. (2004), 'Varieties of Capitalism and Institutional Complementarities in the Macroeconomy: An Empirical Analysis', Cologne: Max Planck-Institute for Social Research, Discussion Paper 04/5.

Huber, Ev. and Stephens, J. D. (2001), Development and Crisis of the Welfare State: Parties and Policies in Global Markets, Chicago: University of Chicago Press.

IMF (2012), Greece: Request for Extended Arrangement Under the Extended Fund Facility, Country Report No. 12/57, Washington DC: International Monetary Fund.

Inácio, Al. (2004), 'Destination Found', Jornal de Notícias, 11 July [in Portuguese].

Institute of Social Security (2013), Practical Guide - Social Integration Income [in Portuguese].

Ioannou, Ch. and Kjellberg, An. (2005), 'Confederations and Mergers. Convenience Rather than True Love', in J. Waddington (ed.), Restructuring Representation: The Merger Process and Trade Union Structural Development in Ten Countries, Brussels: P.I.E-Peter Lang, pp. 337-360.

Journal of the Assembly of the Republic (1994a), $1^{\text {st }}$ Series-No. 52; VI Legislature, 3rd Legislative Session, 25 March, pp. 1746-1768 [in Portuguese].

Journal of the Assembly of the Republic (1994b), $1^{\text {st }}$ Series-No. 76; VI Legislature, 3rd Legislative Session, 25 May, pp. 2474-2489 [in Portuguese].

Journal of the Assembly of the Republic (1996), $1^{\text {st }}$ Series-No. 68; VII Legislature, $1^{\text {st }}$ Legislative Session, 10 May, pp. 2199-2232 [in Portuguese].

Journal of the Assembly of the Republic (2002), $1^{\text {st }}$ Series-No. 20; IX Legislature, $1^{\text {st }}$ Legislative Session, 15 June, pp. 1-31 [in Portuguese].

Katrougalos, G. (1996), 'The South European Welfare Model: The Greek Welfare State, in Search of an Identity', Journal of European Social Policy, vol. 6, no. 1, pp. 39-60.

Kostoulas, V. (2013), 'The Memorandum Will not Come to an End in 2014. Six Findings and Recommendations for the Greek Economy', in Nafteboriki, 22 October [in Greek].

Kouvelakis, St. (2011), 'The Greek Cauldron', New Left Review, no. 72, pp. 17-32.

Leibfried, S. (1992), 'Towards a European Welfare State?', in Z. Ferge and J.E. Kolberg (eds), Social Policy in a Changing Europe, Boulder: Westview Press, pp. 245-279. 
Lisi, M. (2006), 'From Government to Opposition and Then Comeback: Lessons Learned from the Portuguese Socialist Party', in An. Bosco (ed.), Parties and Voters in Southern Europe, Soveria Mannelli: Rubbettino, pp. 47-82 [in Italian].

Magone, J. M. (2005), 'The Internationalization of the Portuguese Socialist Party, 1973-2003', Perspectives on European Politics and Society, vol. 6, no. 3, pp. 491-516.

Matsaganis, M. (2004), Social Solidarity and Its Contradictions: The Role of a Guaranteed Minimum Income Programme in Modern Social Policy, Athens: Kritiki [in Greek].

Matsaganis, M. (2011), Social Policy in Hard Times, Athens: Kritiki [in Greek].

Matsaganis, M. (2013), 'The Guaranteed Minimum Income and its Role in Dealing with the New Social Issue', in National Institute of Labour and Human Resources (ed.), Guaranteed Minimum Income: Approaches and Proposals in View of the Pilot Implementation of the Scheme, Study no. 8/2013, pp. 10-27 [in Greek].

Matsaganis, M. et al. (2003), 'Mending Nets in the South: Anti-Poverty Policies in Greece, Italy, Portugal and Spain', Social Policy \& Administration, vol. 37, no. 6, pp. 639-655.

Matsaganis, M. and Levendi, Ch. (2012), 'The Guaranteed Minimum Income: Fiscal and Distributional Effects', Newsletter 3/2012, Public Policy Analysis Group of the Athens University of Economics and Business, Athens: Kritiki Editions [in Greek].

Media Report (1999), Sourlas’ Political Office, 29 July [in Greek].

Melícias, V. and Pedroso, P. (eds) (1997), Views on the Guaranteed Minimum Income, Lisbon: CES [in Portuguese].

Ministry of Labour and Social Security (2001), National Action Plan for Social Inclusion, 2001-2003, Athens [in Greek].

Ministry of Labour and Social Security (2003), National Action Plan for Social Inclusion, 2003-2005, Athens [in Greek].

National Institute of Labour and Human Resources (2013) (ed.), Guaranteed Minimum Income: Approaches and Proposals in View of the Pilot Implementation of the Scheme, Study no. 8/2013 [in Greek].

Papadokostopoulos, D. G. (2007), 'Expedition Against Poverty', Kathimerini, 18 January [in Greek]. 
Pappas, T. (2003), 'The Transformation of the Greek Party System Since 1951', West European Politics, vol. 26, no. 2, pp. 90-114.

Parliamentary Proceedings (1998a), Standing Parliamentary Committee on Social Affairs, Discussion of the Draft Bill of the Ministry of Health and Welfare on the 'Development of the National System of Social Care', 1-2 September [in Greek].

Parliamentary Proceedings (1998b), Standing Parliamentary Committee on Social Affairs, Law Proposal Submitted to the Greek Parliament by George Sourlas et al., Entitled 'Social Protection for the Weakest', 3 September [in Greek].

Parliamentary Proceedings (1999), Discussion of the Proposal, 'Social Protection for the Weakest', 29 July, pp. 489-510 [in Greek].

Parliamentary Proceedings (2005a), Standing Parliamentary Committee on Social Affairs, Discussion of the Proposal Submitted by Synaspismos, Concerning 'The Institutionalization of a GMI and Accompanying Services of Social Support', 12 April [in Greek].

Parliamentary Proceedings (2005b), Discussion of the Proposal Submitted by Synaspismos, Concerning 'The Institutionalization of a GMI and Accompanying Services of Social Support', 1 December, pp. 2149-2175 [in Greek].

PCP (2010), Constitution, Lisbon: PCP.

Pedroso, P. (1998), 'Rights and Solidarity: Prospects of Integration for All', Sociedade e Trabalho, no. 3, pp. 6-17 [in Portuguese].

Poulakidas, K. (2013), 'Guaranteed Minimum Income; Without a Plan', in Avgi, 24 October [in Greek].

PSD (1992), Programme of the Social Democratic Party, Porto, 13-15 November [in Portuguese].

Público (1999), ‘A Record of Promises', 14 July, p. 7 [in Portuguese].

Público (2002), 'Cáritas Portuguesa in Favour of the RMG', 3 April [in Portuguese].

Recommendation 92/441/EEC, Council Recommendation of 24 June 1992 on Common Criteria Concerning Sufficient Resources and Social Assistance in Social Protection Systems, Official Journal L 245, 26/08/1992, pp. 0046-0048.

Rizospastis (2004), 'The Experience of the Minimum Guaranteed Income', 16 July [in Greek].

Rizospastis (2013), 'Parliamentary Budget Office', 20 November, p. 5 [in Greek]. 
Rodrigues, C. (2004), 'The Redistributive Impact of the Guaranteed Minimum Income Programme in Portugal', School of Economics and Management-DE Working Papers 9-2004.

Rodrigues, C. (2011), 'Minimum Income in Portugal: Changing the Rules in Times of Crisis', Paper Presented at the EUROMOD Workshop at Riga.

Rodrigues, Ed. (2006), "Hard" Paths: The Processes of Social Mobilization of GMI Recipients in V.N. Gaia, PhD Thesis, University of Porto [in Portuguese].

Rühle, Ot. (1939), 'The Struggle Against Fascism Begins with the Struggle Against Bolshevism', American Councillist Journal Living Marxism, vol. 4, no. 8.

Simitis, K. (1989), Development and Modernization of Greek Society, Athens: Gnosi Editions [in Greek].

Simitis, K. (1990), Views on the Political Strategy of PASOK, Athens: Gnosi Editions [in Greek].

Someritis, S. (1933), Dependent Employment and Social Security, Athens [in Greek].

Sotiropoulos, D. (2005), 'Poverty and the Safety Net in Eastern and South Eastern Europe in the Post-Communist Era, in M. Ferrera (ed.) (2005), Welfare State Reform in Southern Europe. Fighting Poverty and Social Exclusion in Italy, Spain, Portugal and Greece, London: Routledge/EUI Studies in the Political Economy of Welfare, pp. 266-296.

Stock, M. J. and Magone, J. M. (1996), 'Portugal', European Journal of Political Research, vol. 30, no. 3-4, pp. 445-452.

SYRIZA (2012), SYRIZA's Updated Programme for the 17 June Elections (1 ${ }^{\text {st }}$ June 2012).

Tsouparopoulos, D. and Triantafyllou, G. (2006), 'The Comeback of the Minimum Guaranteed Income', Kerdos, 4 December [in Greek].

UGT (1998), Guaranteed Minimum Income-An Open Window to the Future, Lisbon: UGT [in Portuguese].

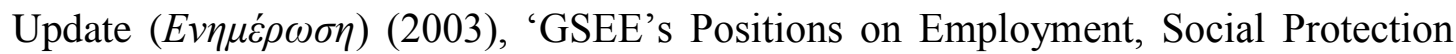
and Developmental Policy', no. 98 [in Greek].

USS/CGTP-In (1994), 7th USS/CGTP-IN Congress, Action Plan [in Portuguese].

To Vima (2008), 'Why Mr. Simitis Put an End to His Collaboration with Tsoukatos in 2000', 22 June [in Greek]. 